\title{
'Equality of opportunity remains a distant ideal'
}

\author{
Dr. Nidhi Gupta (Professor) and Ms. Pooja Kalra (Assistant Professor) \\ Management Department, Rukmini Devi Institute Of advanced Studies, New Delhi.
}

\begin{abstract}
This paper focuses on an issue that almost all the nations are suffering with no matter whether its developing, developed or under developed nation. Equality of opportunity is an ideal that most people, and all mainstream parties, subscribe to. But achieving it is very hard in a society with such wide differences in the resources that people and their families have to develop their talents and fulfill their potential. All people are created equal in rights, dignity, and the potential to achieve great things. True opportunity requires that we all have equal access to the benefits, burdens and responsibilities of our society regardless of race, gender, class, religion, sexual orientation, disability, or other aspects of what we look like or where we come from. Ensuring equal opportunity in the 21st Century demands a nuanced understanding of the progress that is made as a nation, as well as the nature of contemporary bias and systemic inequality. It requires understanding, for example, how stereotypes based on gender, race, and other social characteristics can come together in unique ways that require individualized attention. Discrimination, however, is only a small part of the picture. Probably the most important reason for lack of equality of opportunity is education: both its quantity and quality. Without substantial policy changes, nation's self-image, and the image that will be projected to the world, will diminish - and so will economic standing and stability. Inequality of outcomes and inequality of opportunity reinforce each other - and contribute to economic weakness. So in a nutshell through this paper we have tried to touch the inequalities that are prevailing in a nation that is probably considered to be the super powerful nation of the world-United States of America and the reasons behind that.
\end{abstract}

Key Words: Mainstream Parties, Race, Gender, Discrimination, Stereotypes, Reinforce, Inequalities, Economic standing, Contemporary bias and Economic weakness.

\section{Introduction}

On balance, the current generation in USA is living in a society that is far more inclusive than the one their parents and grandparents grew up in. At work, there are more people that look like minorities and women, serving in high-level positions than in the recent past. Likewise, elected officials across national, state and local levels of government are increasingly diverse as they reflect the communities they serve.

This inclusiveness and increased diversity is a testament to the vision of Dr. King and those who worked alongside him - and to those that carry on his efforts today. This is not to say that americans have already achieved his full vision. Indeed, the notion of a post-racial society is still a myth to many Americans and all must continue to work so that race, gender, ethnicity, religious and sexual orientation are not impediments to growth and opportunity in society.

So, it is the responsibility of all the US citizens, as individuals, employers, employees and communities, to continue in Dr. King's spirit. It is surprising to see how different ethnicities, spiritual beliefs and social values peacefully and productively coexist in US society - and the public discourse about these issues and their impact on the country is, by and large, civilized and forward thinking. People there live longer now. People work longer, too. People change careers and relocate far more often than they have done in the past.

Equality of opportunity is an ideal that most people, and all mainstream parties, subscribe to. But achieving it is very hard in a society with such wide differences in the resources that people and their families have to develop their talents and fulfill their potential.

All people are created equal in rights, dignity, and the potential to achieve great things. True opportunity requires that all have equal access to the benefits, burdens and responsibilities of society regardless of race, gender, class, religion, sexual orientation, disability, or other aspects.

Equal opportunity means treating similarly situated people similarly, while taking account of human, cultural, and other differences. It means, for example, that a person's race, gender, religion, or sexual orientation should be irrelevant to his or her ability to receive quality health care or to own a home. It also means, however, that the health care women and men receive should be appropriate to their different needs. It means considering the needs of Americans who use wheelchairs as well as those who use their feet in designing a home, or a bus or a courthouse. Expecting Americans who have not yet mastered English to navigate a legal system conducted only in English is not equal opportunity. Nor is treating American Indian tribes - endowed by our Constitution with a sovereign status equal to the 50 states - as if they were just another group of communities. Equal opportunity is not treating everyone identically but, rather, treating everyone as an equal. 
The theme of equality is central to nation's founding, with the declaration that "all men are created equal." American history has witnessed the gradual evolution of that core principle from a ruling class that countenanced slavery and subordination toward an egalitarian vision that embraces the inherent equality of all people. Americans fought a civil war in part to give life to this proposition. It is embodied in the Constitution's guarantee of equal protection under law, and in the other Civil War amendments. And epic social movements of the past two centuries have moved America, in fits and starts, further still toward the reality of truly equal opportunity. As Abraham Lincoln said : "Americans should set up a standard maxim for free society, which should be familiar to all, and revered by all; constantly looked to, constantly labored for, and even though never perfectly attained, constantly approximated, and thereby constantly spreading and deepening its influence, and augmenting the happiness and value of life to all people of all colors everywhere."

Equal opportunity is also central to the system of international human rights that the United States helped to craft after World War II and the horrors of the Holocaust. The Universal Declaration of Human Rights states that "All human beings are born free and equal in dignity and rights." It goes on to guarantee all people equal protection of the law, equal pay for equal work, equal access to education, equal access to public service, equal rights as to marriage, and an equal right to vote, among other protections. Virtually every human rights document contains a similar guarantee of equal treatment. And the conventions on the elimination of racial discrimination and discrimination against women make concrete the affirmative obligations of all nations to provide equal opportunity. The race convention, for example, requires governments "to review governmental, national and local policies, and to amend, rescind or nullify any laws and regulations which have the effect of creating or perpetuating racial discrimination wherever it exists." And it recognizes the need, in some cases, for measures that affirmatively promote the inclusion of members of previously excluded groups "as may be necessary in order to ensure such groups or individuals equal enjoyment or exercise of human rights and fundamental freedoms."

\section{Review of Literature}

In the 1960s and 1970s, better-off but not startlingly affluent households had roughly three times the income, after tax, of those near the bottom of the income scale. That gap has widened and, since the early 1990s, the income ratio has been four to one - a fundamental change that has a profound impact on people's life chances.

The National Equality Panel, in its report looked at how economic inequalities such those in wages, income and wealth are related to people's circumstances and characteristics, such as gender, ethnicity, disability status or the kind of area they live in. Deep-seated and systematic differences have been found between social groups.

There are some signs of progress. Twelve years ago, women took home only 53\% of the income that men do. Women still get less, but now the figure is $64 \%$. And the largest qualification gaps between ethnic groups have narrowed or disappeared.

But members of all non-white minority ethnic groups are less likely to be in paid work than white British men and women. When people respond to job advertisements, those with apparently Asian or Caribbean names are less likely get interview offers, even if the rest of the CV is the same. Women are better qualified overall than men up to the age of 44 , but their median hourly pay is $21 \%$ less than that for men. Apart from the best qualified women working in the public sector, women's pay does not rise as they get older.

However, wherever we looked, differences within groups are far wider than those between groups. The best paid one tenth of women, for instance, have hourly pay more than 3.5 times that of the least well-paid one tenth. So even if the differences in average incomes between groups disappeared, the country would remain almost as unequal overall.

Advantages and disadvantages reinforce themselves over the life cycle, and often on to the next generation. It matters more who your parents are in Britain than in many other countries, particularly those with less inequality. Climbing up a social ladder is harder when the rungs are further apart. At the other end, those who start higher up will, unsurprisingly, fight harder to make sure that their children don't slip down.

And they have the resources to do this. Wealth makes a huge difference to people's ability to afford houses in the catchment areas of the best schools, private tutors or private education, and to help finance the master's degrees now essential for some careers, or to help children get on the housing ladder.

Analysis by the Office for National Statistics of the new Wealth and Assets Survey shows that half of households nearing retirement (aged 55-64) from higher professional or managerial occupations have wealth (including pension rights) over $£ 900,000$, and a tenth over $£ 2 \mathrm{~m}$. Half of those of the same age from routine occupations have under $£ 150,000$, and a tenth have less than $£ 8,000$ with which to face retirement - although that retirement is likely to be shorter, given the stark differences in the mortality rates between those with high and low wealth among people over 50. 


\section{Research Methodology}

This is an exploratory research based solely on insights drawn from the analysis of the existing literature of different studies, reports, periodicals and books related to the topic of study in order to investigate the relationships between inequality and factors responsible for it.

This research work will serve as a means to help acquire useful information or knowledge about the subject area i.e. existing literature, not only topic under consideration is theorize, but also formulates and discusses the proposition that will help illuminate and discuss some ways to reduce inqualities.

\section{Research Problem}

This paper focusses on the wide inequalities that are prevalent in the United States of America. It's quite ironic that the nation that is considered to be the most powerful nation of the world also suffers from the inequalities as far as opportunities are concerned. This paper foremostly touches the inequality prevalent and the reasons behind it and most importantly the ways to deal with this inequality

Ensuring equal opportunity in the 21 st Century demands a nuanced understanding of the progress that America has made as a nation, as well as the nature of contemporary bias and systemic inequality. It requires understanding, for example, how stereotypes based on gender, race, and other social characteristics can come together in unique ways that require individualized attention-what Shirley Chisolm called, in the case of African-American women, "the twin jeopardy of race and sex...and the psychological and political consequences which attend them." It includes the reality that people are all capable of bias and discrimination, including against members of one's own group. And it requires acknowledging and addressing the instances of overt discrimination and bigotry that do remain in American society without believing that those are the only kind of inequality worthy of our attention.

Finally, equal opportunity means not only ending overt and intentional discrimination, but also rooting out subconscious bias and reforming systems that unintentionally perpetuate exclusion. It requires proactive efforts to remake our institutions in ways that ensure fairness and inclusion. As the Rev. Dr. Martin Luther King, Jr. wrote, "with equal opportunity must come the practical, realistic aid which will equip [people] to use it."

President Obama's second Inaugural Address used soaring language to reaffirm America's commitment to the dream of equality of opportunity: "We are true to our creed when a little girl born into the bleakest poverty knows that she has the same chance to succeed as anybody else, because she is an American; she is free, and she is equal, not just in the eyes of God but also in her own."

The gap between aspiration and reality could hardly be wider. Today, the United States has less equality of opportunity than almost any other advanced industrial country. Study after study has exposed the myth that America is a land of opportunity. This is especially tragic: While Americans may differ on the desirability of equality of outcomes, there is near-universal consensus that inequality of opportunity is indefensible. The Pew Research Center has found that some 90 percent of Americans believe that the government should do everything it can to ensure equality of opportunity.

Perhaps a hundred years ago, America might have rightly claimed to have been the land of opportunity, or at least a land where there was more opportunity than elsewhere. But not for at least a quarter of a century. Horatio Alger-style rags-to-riches stories were not a deliberate hoax, but given how they've lulled Americans into a sense of complacency, they might as well have been.

It's not that social mobility is impossible, but that the upwardly mobile American is becoming a statistical oddity. According to research from the Brookings Institution, only 58 percent of Americans born into the bottom fifth of income earners move out of that category, and just 6 percent born into the bottom fifth move into the top. Economic mobility in the United States is lower than in most of Europe and lower than in all of Scandinavia.

Another way of looking at equality of opportunity is to ask to what extent the life chances of a child are dependent on the education and income of his parents. Is it just as likely that a child of poor or poorly educated parents gets a good education and rises to the middle class as someone born to middle-class parents with college degrees. Even in a more egalitarian society, the answer would be no. But the life prospects of an American are more dependent on the income and education of his parents than in almost any other advanced country for which there is data.

How can this be explained? Some of it has to do with persistent discrimination. Latinos and AfricanAmericans still get paid less than whites, and women still get paid less than men, even though they recently surpassed men in the number of advanced degrees they obtain. Though gender disparities in the workplace are less than they once were, there is still a glass ceiling: women are sorely underrepresented in top corporate positions and constitute a minuscule fraction of C.E.O.'s.

Discrimination, however, is only a small part of the picture. Probably the most important reason for lack of equality of opportunity is education: both its quantity and quality. After World War II, Europe made a 
major effort to democratize its education systems with the G.I. Bill, which extended higher education to Americans across the economic spectrum.

But then America changed, in several ways. While racial segregation decreased, economic segregation increased. After 1980, the poor grew poorer, the middle stagnated, and the top did better and better. Disparities widened between those living in poor localities and those living in rich suburbs - or rich enough to send their kids to private schools. A result was a widening gap in educational performance - the achievement gap between rich and poor kids born in 2001 was 30 to 40 percent larger than it was for those born 25 years earlier, the Stanford sociologist Sean F. Reardon found.

Of course, there are other forces at play, some of which start even before birth. Children in affluent families get more exposure to reading and less exposure to environmental hazards. Their families can afford enriching experiences like music lessons and summer camp. They get better nutrition and health care, which enhance their learning, directly and indirectly.

Americans are coming to realize that their cherished narrative of social and economic mobility is a myth.

Unless current trends in education are reversed, the situation is likely to get even worse. In some cases it seems as if policy has actually been designed to reduce opportunity: government support for many state schools has been steadily gutted over the last few decades — and especially in the last few years. Meanwhile, students are crushed by giant student loan debts that are almost impossible to discharge, even in bankruptcy. This is happening at the same time that a college education is more important than ever for getting a good job.

Young people from families of modest means face a Catch: without a college education, they are condemned to a life of poor prospects; with a college education, they may be condemned to a lifetime of living at the brink. And increasingly even a college degree isn't enough; one needs either a graduate degree or a series of (often unpaid) internships. Those at the top have the connections and social capital to get those opportunities. Those in the middle and bottom don't. The point is that no one makes it on his or her own. And those at the top get more help from their families than do those lower down on the ladder. Government should help to level the playing field.

Americans are coming to realize that their cherished narrative of social and economic mobility is a myth. Grand deceptions of this magnitude are hard to maintain for long - and the country has already been through a couple of decades of self-deception.

Without substantial policy changes, Americans self-image, and the image they project to the world, will diminish - and so will there economic standing and stability. Inequality of outcomes and inequality of opportunity reinforce each other - and contribute to economic weakness, as Alan B. Krueger, a Princeton economist and the chairman of the White House Council of Economic Advisers, has emphasized. We have an economic, and not only moral, interest in saving the American dream.

Policies that promote equality of opportunity must target the youngest Americans. Firstly it has to be made sure that mothers are not exposed to environmental hazards and get adequate prenatal health care. Then, reversing the damaging cutbacks to preschool education, a theme Mr. Obama emphasized. All children should have adequate nutrition and health care - not resources have to be provided, but if necessary, incentivize the parents, by coaching or training them or even rewarding them for being good caregivers. The right says that money isn't the solution. They've chased reforms like charter schools and private-school vouchers, but most of these efforts have shown ambiguous results at best. Giving more money to poor schools would help. So would summer and extracurricular programs that enrich low-income students' skills.

\section{Conclusion}

Finally, it is unconscionable that a rich country like the United States has made access to higher education so difficult for those at the bottom and middle. There are many alternative ways of providing universal access to higher education, from Australia's income-contingent loan program to the near-free system of universities in Europe. A more educated population yields greater innovation, a robust economy and higher incomes - which mean a higher tax base. Those benefits are, of course, why America is long been committed to free public education through 12th grade. But while a 12th-grade education might have sufficed a century ago, it doesn't today. Yet America hasn't adjusted our system to contemporary realities.

The steps outlined in this paper are not just affordable but imperative. Even more important, though, is that it cannot be afforded to let the country drift farther from ideals that the vast majority of Americans share. The Nation will never fully succeed in achieving Mr. Obama's vision of a poor girl's having exactly the same opportunities as a wealthy girl. But efforts could be done much, much better, and must not rest until it is done. 


\section{References}

[1]. - -Equal Opportunity, Our National Myth

By JOSEPH E. STIGLITZ http://opinionator.blogs.nytimes.com/2013/02/16/equal-opportunity-our-nationalmyth/? php=true\& type=blogs\& $\mathrm{r}=0$

[2]. -Inequality and mobilityAgainst equality of opportunity Apr 20th 2012, 21:10 by W.W. | IOWA CITY http://www.economist.com/blogs/democracyinamerica/2012/04/inequality-and-mobility

[3]. -http://www.theguardian.com/society/joepublic/2010/jan/27/social-groups-equality-gap-Sustaining the Dream of Equality of Opportunity by Gina Adams | Google+ Posted at 8:33 am in civil rights diversity martin luther king jr memorial MLK $\underline{\text { race }}$ relations Washington DC

[4]. Pérez-González, Francisco. 2006. "Inherited Control and Firm Performance.” American Economic Review 96(5): 1559 - 88.

[5]. Roemer, John E. 2004. "Equal Opportunity and Intergenerational Mobility: Going Beyond Intergenerational Income Transition Matrices." Chap. 3 in Generational Income Mobility in North America and Europe, edited by Miles Corak. Cambridge University Press.

[6]. http://www.americanthinker.com/2014/02/equality_of_opportunity.html 